DIW BERLIN

Discussion

Papers

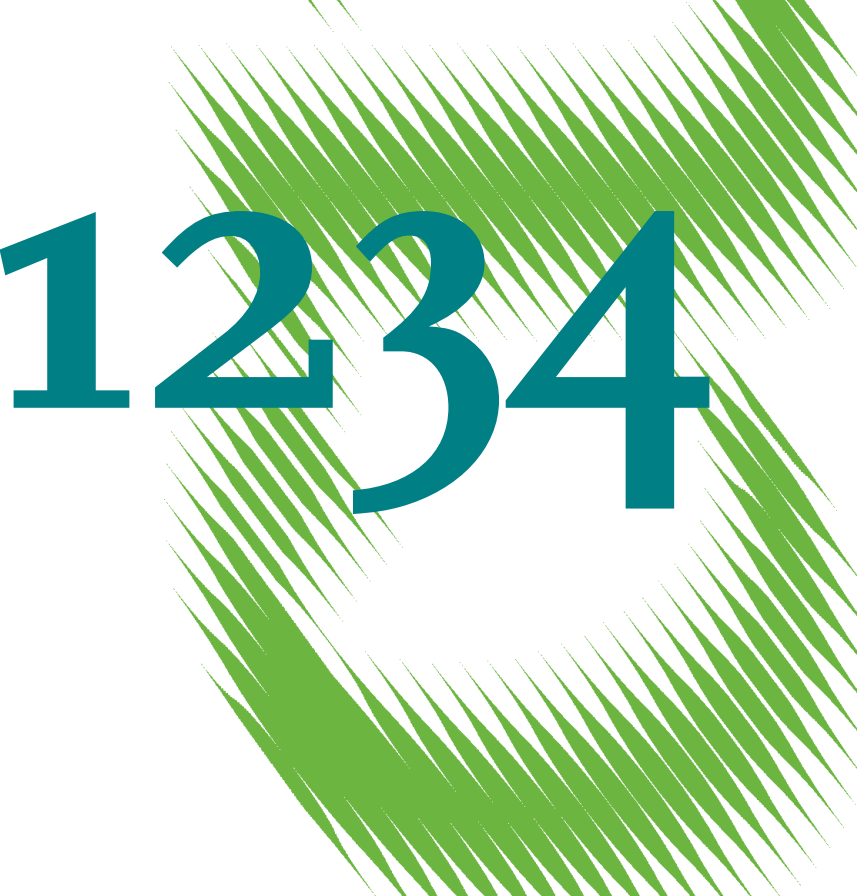

Family and Labor Market Choices Requirements to Guide Effective Evidence-Based Policy 
Opinions expressed in this paper are those of the author(s) and do not necessarily reflect views of the institute.

IMPRESSUM

(C) DIW Berlin, 2012

DIW Berlin

German Institute for Economic Research

Mohrenstr. 58

10117 Berlin

Tel. $+49(30) 89789-0$

Fax +49 (30) $89789-200$

http://www.diw.de

ISSN print edition $1433-0210$

ISSN electronic edition 1619-4535

Papers can be downloaded free of charge from the DIW Berlin website:

http://www.diw.de/discussionpapers

Discussion Papers of DIW Berlin are indexed in RePEc and SSRN:

http://ideas.repec.org/s/diw/diwwpp.html

http://www.ssrn.com/link/DIW-Berlin-German-Inst-Econ-Res.html 


\title{
Family and labor market choices - requirements to guide effective evidence-based policy
}

\author{
Anna Kurowska \\ Michal Myck \\ Katharina Wrohlich ${ }^{1}$
}

July 31, 2012

\begin{abstract}
:
Microsimulation methods and models of labor market decisions have attracted a lot of attention as an approach to the assessment of consequences of family related policies in the area of labor market and fertility. We set these models in the context of relevant demographic theories and present them from the point of view of their potential as tool to guide effective policy making with the aim to reconcile the objectives of increasing female participation and fertility and reducing poverty levels among families with children.
\end{abstract}

Keywords: microsimulation, labor supply, fertility, evidence-based policy

JEL Classification: J22, J13, J18

\footnotetext{
${ }^{1}$ Anna Kurowska is Assistant Professor at the Institute of Social Policy at the University of Warsaw; e-mail: a.kurowska@uw.edu.pl. Michal Myck is director of the Centre for Economic Analysis, CenEA and a Research Associate at DIW-Berlin; e-mail: mmyck@cenea.org.pl. Katharina Wrohlich is Senior Researcher at the German Institute of Econmic Research (DIW Berlin); e-mail: kwrohlich@diw.de. The paper was written with financial support from the Foundation for Polish Science (Parent-Bridge Programme) as part of the project "Joint influences of family and labour market policies on labour market participation and fertility decisions of men and women" coordinated by Anna Kurowska.
} 
Low and often diminishing rates of fertility in Europe, together with low female labor market participation levels have been the focus of the European socio-economic policy for a long time. Both of these in the context of the processes of population ageing represent some of the most important challenges for policy makers in the coming decades. In many countries low employment among women has been an issue of particular attention and it has been recognized for a long time that decisions - in particular of women, but also of men concerning work, and decisions regarding whether to have children, and if so how many, are strongly interrelated (e.g. OECD, 2001). In parallel to this there has been a related ongoing debate concerning the financial situation of families with children with a significant focus on the rates of child poverty, and adequate state support to families with children (e.g. OECD, 2009, 2011). The usual background to the latter policy debate is the concern about the sufficient level of "investment" in the current generation of children to ensure the best possible development of their potential and their welfare in the future. At the same time the financial consequences of having children are one of the key determinants of fertility, and child-related financial support is often considered as an important element of fertility policies.

The three policy goals, i.e. high fertility rates, high rates of employment and low rates of child poverty, are addressed by various sets of policy measures in all European countries (OECD, 2011). The policies range from the guarantees of parental leave and child benefits, to numerous forms of child-related employment subsidies, free child care provision or child tax credits. Importantly from the point of view of effectiveness of the policies, some of those which aim at either one of these goals have consequences on the other, and in many instances the consequences may counteract each other. For example, financial support for children helps to reduce child poverty and may also have positive indirect effects on fertility decisions. At the same time, however, the level of out of work benefits may act to discourage work of first earners in the family, while child tax credits or in-work benefits may 
reduce the financial incentives on second earners. ${ }^{2}$ Similarly, long and generous maternity or parental leave may lead to increased fertility (e.g. Lalive and Zweimuller 2005, Ronsen 2004, Olah 2003), but at the same time could discourage employers from offering work to potential parents, and parental labor market protection may make it more difficult for parents to find new employment.

To develop an efficient and consistent institutional setup with the aim to target the above mentioned objectives it is essential to understand the role of policy in affecting these goals and in particular the interaction between the different measures.

The discussion presented in this paper provides an overview of a particular type of approach to the analysis of policies with regard to these three goals, namely the use of microsimulation. We show the extent to which using microsimulation may inform the public debate on the degree of effectiveness of various policies, the difficulties faced by researchers in the area, and potential ways to address them. We pay special attention to the requirements in terms of research infrastructure which are essential to facilitate a comprehensive approach to evidence based policy making in this area.

In the analysis we outline some key theories relating fertility and labor market outcomes from the demographic literature and discuss the interpretation of the economic model in this context. This in our view helps in understanding the advantages and limitations of the standard economic models of choice in these domains. The paper on the one hand offers a review of the existing literature on modeling of support for families with children and the resulting labor market and fertility outcomes using the micro-simulation approach. On the other hand, we discuss the research tools necessary for identification of key parameters determining the outcomes, thus allowing for assessment of policy measures. As we show all major assessments of implemented or planned policies require significant resources, both in the form of detailed data as well as complex microsimulation infrastructure.

\footnotetext{
${ }^{2}$ See, e.g. Blundell et al. (2000), Bargain and Orsini (2006), Haan and Myck (2007), Bargain et al. (2010).
} 
In Section 2 of this paper we provide a brief overview of the heterogeneity in female employment and fertility rates in Europe which form a background to the discussion. In Section 3 we begin with an outline of potential channels of interrelation between fertility and labor market decisions by presenting the most important theories in demography to provide a general context for the discussion of the economic model. Following this we start the analysis of the economic approach with the simplest labor supply set-up and from there build up the discussion to present the much more complex nature of the problems captured by recent applications. The extensions of the basic model including developments in joint estimation of labor market and fertility decisions are presented in Section 4. Section 5 outlines the approach to estimation of the parameters of the decision making process drawing on the rich labor supply literature and showing the significant degree of progress made in recent years to extend the initial basic models. In this section we point out the important requirements in terms of data availability and microsimulation research infrastructure which determine the degree of detail which can be reliably estimated. Section 5 concludes the paper and in the Appendix we provide an overview of some of the more important policy estimates using the microsimulation approach.

\section{Female employment, fertility and population ageing in Europe}

Low employment and low fertility rates would probably not be major concerns on their own right, but when considered from the point of view population ageing and the future stability of the public sector finances, or the effect parental employment has on child poverty they have both become issues of very vigorous public debate. A particularly interesting background to this discussion is the high heterogeneity of employment and fertility, both in terms of the levels as well as the pattern of changes. In Figures 1 and 2 we show trends in these outcomes for a selected group of European countries. Over the last twenty years fertility rates of many countries have converged to the level of about 1.3 with significant drops in fertility in such countries like Czech Republic, Lithuania or Poland, and continuously low rates in Spain and Germany. At the same time in countries such as the Netherlands, Sweden or the UK fertility rates are at much higher levels of about 1.8-1.9. While they have been relatively stable in the Netherlands and the UK, Sweden has seen a significant drop in 
fertility in the 1990s, and following that an almost equally strong recovery in the 2000s. Interestingly throughout this period employment rates of Swedish and British women remained one of the highest in Europe, and female employment rates in the Netherlands significantly improved from about $47 \%$ to $69 \%$. In other countries, such as the Czech Republic, Germany or Poland employment rates have been relatively stable at much lower levels of about $50-60 \%$, and from among the countries we look at, the one which has experienced the highest improvement in female employment has been Spain where the rates increased from $31 \%$ in the early 1990 s to about $52 \%$ in 2010 . What is striking, when we look at Figures 1 and 2 is the fact that there is no clear pattern of employment and fertility rates and if there is any relationship one could draw from it, it is that these two are positively correlated. Heterogeneity of female employment and fertility rates in Europe, the one hand suggests potentially important role of cultural differences and rapid changes in this respect, but on the other points towards a significant role of different policy environments.

Table 1

Old age dependency ratio for selected European countries.

\begin{tabular}{l|ll|llll|}
\hline & \multicolumn{2}{|c|}{ Actual } & \multicolumn{4}{c}{ Projected } \\
\hline Czech Republic & $\mathbf{2 0 0 0}$ & $\mathbf{2 0 1 0}$ & $\mathbf{2 0 2 0}$ & $\mathbf{2 0 3 0}$ & $\mathbf{2 0 4 0}$ & $\mathbf{2 0 5 0}$ \\
Germany & 0.198 & 0.216 & 0.304 & 0.343 & 0.401 & 0.501 \\
Spain & 0.239 & 0.314 & 0.358 & 0.472 & 0.564 & 0.581 \\
Lithuania & 0.245 & 0.247 & 0.289 & 0.355 & 0.467 & 0.569 \\
Netherlands & 0.208 & 0.233 & 0.266 & 0.352 & 0.418 & 0.473 \\
Poland & 0.200 & 0.228 & 0.308 & 0.402 & 0.473 & 0.465 \\
Sweden & 0.176 & 0.190 & 0.269 & 0.352 & 0.399 & 0.530 \\
United Kingdom & 0.269 & 0.277 & 0.335 & 0.372 & 0.404 & 0.417 \\
\hline
\end{tabular}

Source: EUROSTAT.

Notes: Old age dependency ratio defined as the ratio of population aged 65 and over to population aged 15 to 64.

In Table 1 we present the old-age dependency ratio for the eight countries including projections in this ratio up to 2050. With the exception of the UK and Sweden - the two countries with highest fertility rates - old age dependency ratio in 2050 is above $45 \%$ in all countries. In Germany and in Spain the projected old-age dependency is as high as $58.1 \%$ and $56.9 \%$ respectively, while in Poland it is projected to reach 53\%. Naturally, the current fertility rates translate into the demographic situation in the future. As one would expect 
there is a clear and significant pattern in the relationship between current fertility and future old-age dependency. This is demonstrated in Figure 3 for all 27 EU countries. With the exception of Luxemburg and Cyprus, the countries with highest current fertility rates of 1.8 and above will have an old-age dependency ratio around or below $45 \%$. Among the countries with lowest fertility (Germany, the Mediterranean countries and many of the New Member States) old-age dependency ratio is expected to exceed 55\%.

Figure 1

Fertility rates in selected European countries, 1990-2010

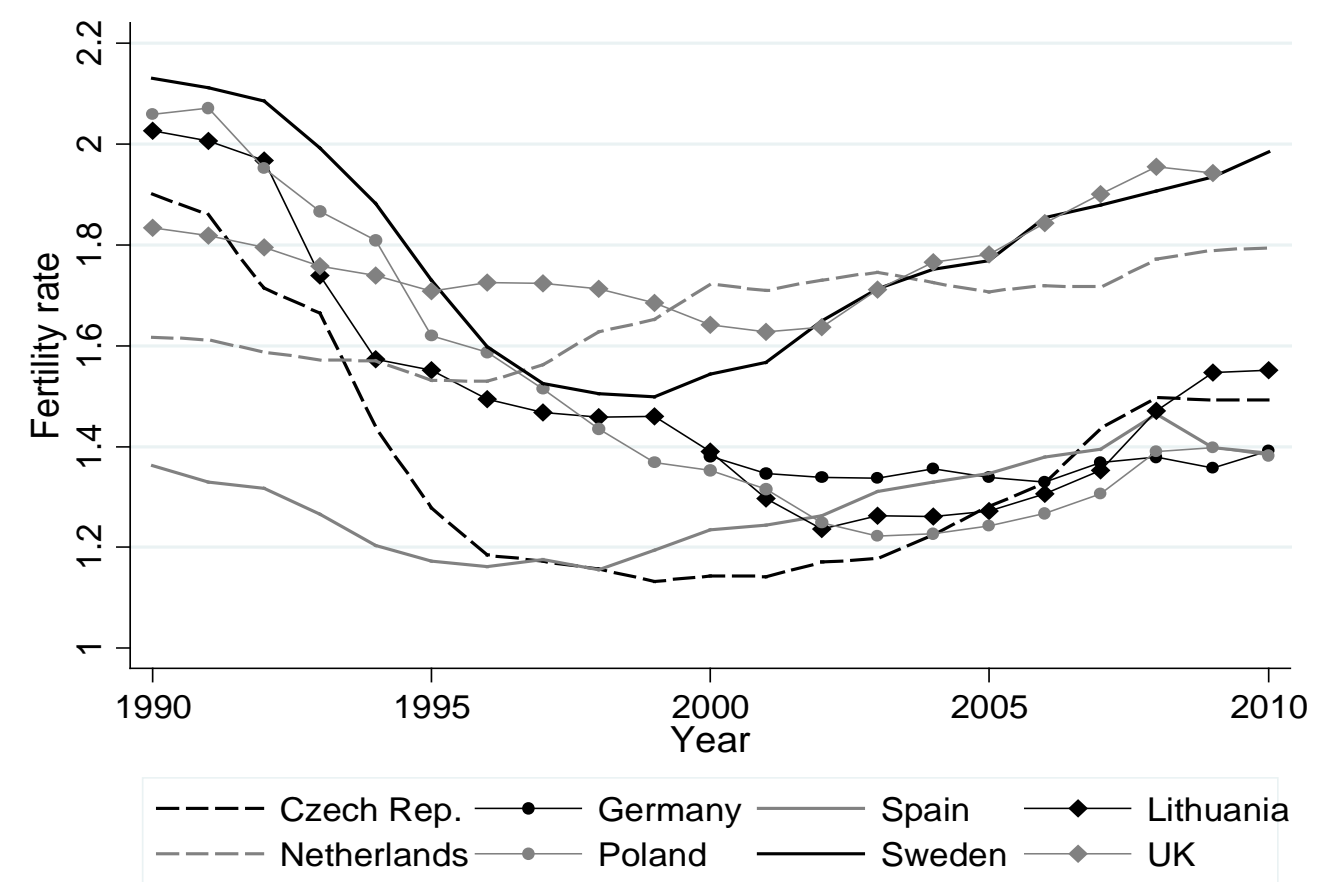

Source: Based on data from EUROSTAT. 
Figure 2

Female employment rates in selected European countries, 1990-2010

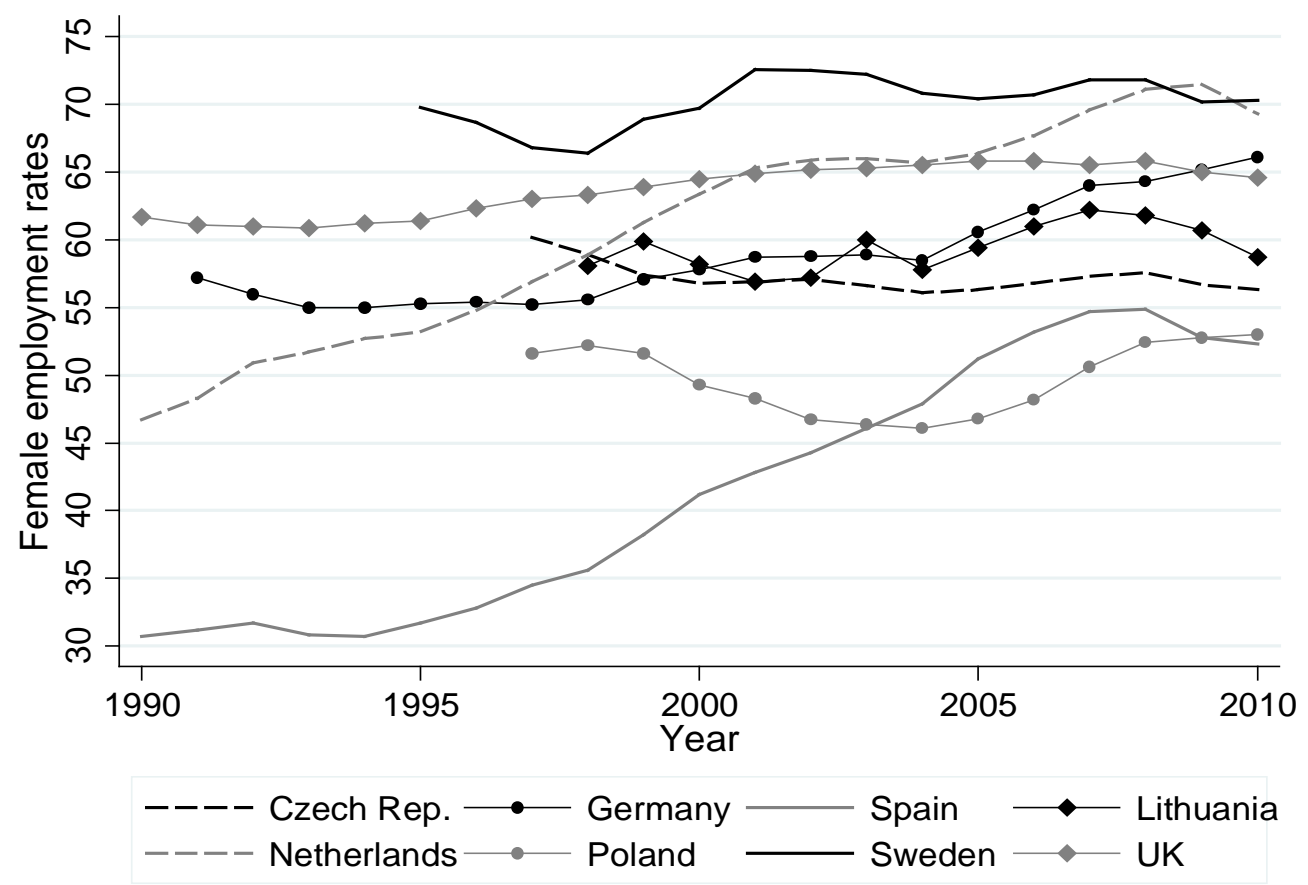

Source: Based on data from EUROSTAT.

Figure 3

Current fertility rates and future old age dependency in Europe

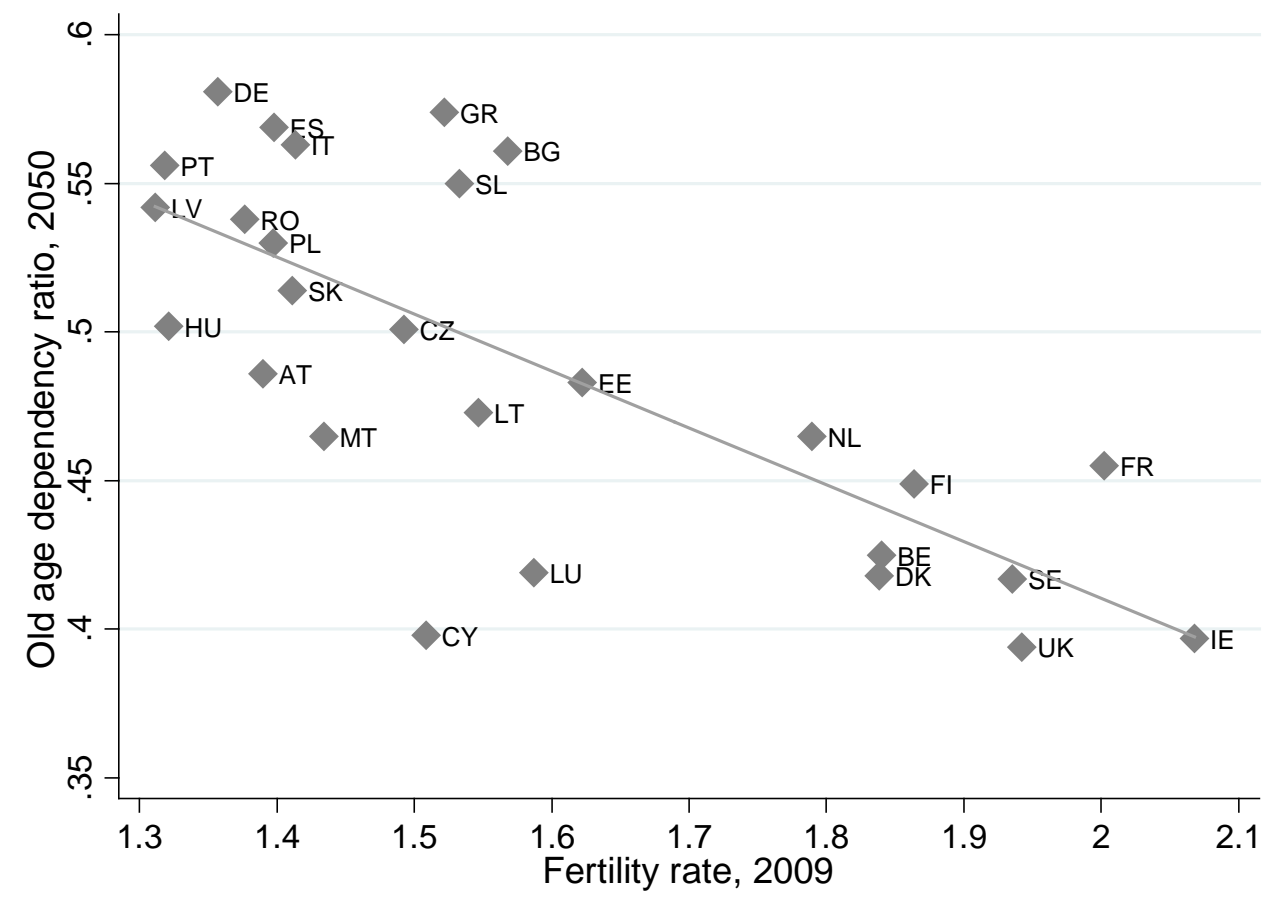

Source: Based on data from EUROSTAT.

Notes: Figure includes a linear regression line of fitted values. Old age dependency ratio defined as the ratio of population aged 65 and over to population aged 15 to 64 . 


\section{$3 \quad$ Family structure and labor market choices - interpreting the simplest static model}

This section combines the typology used to interpret labor market and fertility choices in the demographic literature with the economic approach to modeling of these choices. We argue that while not all aspects of fertility and employment choices can be fully captured by the economic model, the latter accounts for a broad range of most important and policy relevant factors. What is limiting the empirical analysis is not so much the nature of the model, but rather the availability of research infrastructure necessary for its implementation.

The discussion of patterns of labor market and fertility decisions in the demographic literature has focused on the role of the context within which men and women make their choices. Blossfeld (1995) called this a "family system" which covers such factors as "cultural values, family and religious traditions, and family policies". This has been followed by a more specific categorization of Liefbroer and Corijn (1999) who discussed the differences in the degree of incompatibility of labor force participation and family formation within different contexts, identifying them as cultural and structural. In this approach cultural incompatibility "relates to broad ideologies, values, and norms concerning the role of women", while structural incompatibility "relates to actual societal opportunities and constraints on the roles of women". The latter could also be referred to as the institutional context, and accommodates such constraints as availability of formal childcare, as well as legal and financial support for families with children. ${ }^{3}$

These constraint-focused theories have developed alongside the approach stressing the individual level determinants of labor market and fertility outcomes - on the one hand relating to budget constraints faced by families (Easterlin 1976, 1980; Macunovich 1996) and on the other hand focused on preferences (Hakim, 2000, 2003). While a crucial aspect of Macunovich's (1996) approach has been the role assigned to household's material aspirations which determine the relative effects of income and wages, Hakim (2003)

\footnotetext{
${ }^{3}$ In the discussion below we use the term "institutional" rather than "structural" since the latter has a very specific meaning in the economics literature.
} 
allocates women to three groups in accordance to their preference types with regard to work and family, an approach similar to that of career orientation proposed by Willekens (1991). Hakim's work was to constitute "a qualitative break from economic theories of fertility change" and to provide "an alternative basis for the development of family policy" (Hakim, 2003, p. 349).

As we argue below the economic approach to labor market and family decisions in many respects accommodates these theories. The outlined demographic approach, however, allows to better understand the potential limitations of estimated parameters of the standard economic model and thus provides valuable insights to the interpretation of estimated consequences of socio-economic policy. The economic models clearly have their limitations, but we argue that generally speaking the demographic typologies such as Willekens' (1991) career orientation or Hakim's (2003) preference types should be accommodated in the model through a careful treatment of both observed and unobserved heterogeneity. Generally speaking the more information is available on individuals in the data set used for estimations, the greater is the extent to which one can rely on the differentiation of preferences through observed heterogeneity, and as a result the easier it is to identify the specific preference types. Naturally there will always be individual characteristics which will be unobserved to the researcher, but in such a case estimations allowing for unobserved heterogeneity help shed light on family types with respect to preferences and, importantly, correct for any bias of preference parameters which can result from ignoring the unobserved factors. The important advantage of the economic approach described in this paper is that it accounts for the financial consequences of individuals' decisions, which allows to incorporate government tax and benefit policy with respect to work and family. The models thus not only allow to verify the sociological typology of preference types but, if correctly specified and estimated, allow to simulate alternative policy approaches.

We begin the discussion with a consideration of the simplest static form of an economic model which addresses the problem of labor market choices, and subsequently build on this example a more complex and comprehensive framework with a view of a life-cycle approach to fertility and labor market decisions. Since the static model does not allow for analysis of 
inter-temporal decisions it cannot capture fertility choices and uses family structure only as conditioning information. The static models of labor market choice however, have been used widely in the analysis of family related tax and benefit policies and have been instrumental in the understanding of implications of numerous child-related policies (e.g. Duncan and Giles, 1996; Bingley and Walker, 1997; Brewer et al. 2006; Blundell et al., 2000; Blundell, 2001; Levy et al. 2009, Haan and Myck, 2007).

\subsection{Labor market choices in a static context}

The models we discuss in this paper focus in particular on individuals in couples, and most of the discussion is built around the traditional unitary framework (e.g. Aaberge et al., 1995; van Soest, 1995; Blundell, 2000). This approach assumes that individual preferences of the two members of a couple are combined into a single utility function specified as:

$$
U_{i}=u\left(c_{i}, l_{m}, l_{f}\right)
$$

where $U_{i}$, the utility of the couple is a function of contemporaneous consumption of the couple $\left(c_{i}\right)$, and leisure time of the two partners $-I_{m}$ (male's leisure), and $I_{f}$ (female's leisure). All parameters in this function relate to values and valuations at time $t$, when the decision of the couple is assumed to be made. Naturally, this type of approach makes a very strong assumption concerning optimization over time, as it implies either very myopic, short-term preferences, or alternatively extremely high discount rates making any future implications of period t's decision irrelevant. As a result, analysis in this context cannot explicitly take into account fertility choices which by nature involve optimization over time and are made in reaction to intertemporal incentives. For this to be the case one needs to consider individual choices over time and observe changes in family composition. Additionally the assumption made in equation (1) that preferences of the two partners can be represented by a single utility function, violates the individual approach to optimization, and implies conclusions often falsified in empirical research. Numerous advancements have been made in the context of family labor market choices in this respect, in particular through the development of the collective model (Chiappori, 1992). This model by assuming efficient allocation of 
resources between the members of the household allows, under certain conditions, for identification of individual preferences. Chiappori's model has been extended to allow for possible inclusion of children as an example of "public goods" (Blundell, Chiappori, Meghir, 2005), but as Meghir and Phillips (2010) point out the model is "currently better developed theoretically than empirically" and it has so far not been successfully estimated in a form which would include children and a full tax and benefit system, though there have been numerous attempts to account for the collective nature of households in various types of applications. ${ }^{4}$ However most empirical applications in the labor supply literature still rely on the unitary specification described here.

The choices made by the couple concerning their level of consumption and leisure are the consequences of maximizing of utility function (1), subject to a budget constraint, which is usually written as:

$$
c_{i}+l_{f} w_{f}+l_{m} w_{m}=y_{f}+y_{m}+y_{s}+w_{f}(T)+w_{m}(T)
$$

where $c_{i}$ is total household consumption (the price of which is normalized to 1 ), $w_{m}$, and $w_{f}$ are hourly wages, $T$ is total time available for work, $y_{m}$, and $y_{f}$ are individual non-labor incomes assignable to members of the couple, and $y_{s}$ is non-labor income which cannot be assigned to the members individually. In practice incomes of the couple will be subject to some tax-benefit function, $\gamma$, and so the budget constraint can be written as:

$$
c_{i}=\gamma\left[y_{f}+y_{m}+y_{s}+w_{f}\left(T-l_{f}\right)+w_{m}\left(T-l_{m}\right)\right]
$$

In equation (3), as in subsequent equations, $\gamma$ is a generalized function including all forms of direct taxes and benefits and accounting for various exceptions which affect the final disposable income of the family. In this simplified model the couple will choose its optimal level of male and female leisure as well as the level of consumption at time $t$ to maximize its

\footnotetext{
${ }^{4}$ For example papers by Beninger et al. (2006), Myck et al. (2006) and Vermeulen et al. (2006) use a combination of calibration and estimation to examine potential features of a collective model in the presence of children and in the case of non-participation and non-convex budget sets.
} 
level of utility subject to the constraint it faces, and the role of the researcher would be to identify the parameters of this utility function or preferences implied by it. This in turn allows estimation of the effects of potential changes to the financial incentives the couple faces, which are subject of policy decision.

\subsection{Determinants of choice in the simplest case}

\subsubsection{Heterogenous preferences}

The way preferences are estimated in the economic model outlined above allows to account for preference heterogeneity conditional on observable characteristics such as age of partners, their education, region, etc. Naturally a very important determinant of the relative valuation of leisure and consumption is also the family composition, usually represented by the number and ages of children. We would expect also the diversity of preferences to be shaped by various other individual characteristics, such as family history, upbringing, schooling, work experience, health, migration and the history of childbearing. In the estimations which identify the preferences the choice of those characteristics is usually determined by the availability of data and statistical tests measuring the significance of specific items.

From the point of view of the demographic theories described above it is important to remember that preferences estimated in such models will be likely to "pick up" the more general broader context within which decisions are made including cultural environment or social norms. If this context is entirely reflected in individual preferences, i.e. if culture or social norms "translate" into preferences, then the model should be able to accommodate these and allow for correct interpretation of the estimated coefficients. It is however possible that this context acts as an additional constraint on choices, if for example the distribution of individual preferences in the society has externality effects on particular individuals by implying some stigma effects associated with particular choices. In this case, ignoring such constraints will lead to biased estimates, since in the model the choices observed by the researcher will be entirely associated with preferences conditional only on the modeled budget constraint. For example in a society where female labor market 
activities are "stigmatized" the estimated models, which rely on the observed frequency and intensity of work among women, would assign a high "preference" for leisure among women while in fact, the observed distribution of hours of work would to some extent reflect the constraints implied by the stigma.

Children are a very important "characteristic" of the families which we would expect to be reflected in the preferences over consumption and leisure. The number and ages of children may affect the level of consumption, and they can be expected to influence the valuation of parents' leisure time. This can take the form of necessary care of children, or the desire to spend leisure time with them. The estimated models generally cannot distinguish these two factors and assign all time spent not in work as leisure, as a result associating low labor market activity with preference for leisure. However, in as much as the time spent at home with children is a result of choice and not of additional constraints, policy evaluations on the basis of the estimated model will correctly reflect the expected reaction of families on the labor market.

Naturally in any estimation a significant proportion of the variation in labor market outcomes will remain unexplained in the estimation of preferences because a large proportion of the determinants of preferences will not be observed. This relates not only to items like intelligence, ambition, etc., but also to the role of habits and the dynamic nature of the labor market environment. These unobserved characteristics may incorporate various broad cultural aspects, such as features which in the "preference types" approach distinguish the types (and are otherwise not observed and not correlated with observables). There have been a number of solutions proposed to address this issue, the problem of socalled unobserved heterogeneity, and we return to them in Section 5.

\subsubsection{The budget constraint and the institutional context}

As in the above example of female work generally, there may in fact be actual constraints, beyond the budget constraint as modeled in equation (3), which will bias the results and which may lead to erroneous conclusions regarding simulated policy effects. These constraints may result from the cultural or institutional contexts. For example they can take 
the form of "preference externalities" we referred to above. On the other hand there may be constraints on the institutional side in domains such as childcare, which again may get reflected in the estimated preference parameters if parents reduce work effort as a result. An important distinction between institutional constraints and the other constraints related to the cultural context is that institutional factors are easier to incorporate in the analysis through modification of the budget constraint. This applies to issues such as childcare but also to other factors which affect the actual budget constraint faced by the families as opposed to the modeled budget constraint known to the researcher.

Detailed modeling of the budget constraint which the families face is central for the correct identification of preferences. The modeling has to take detailed account of the tax and benefit function $\gamma$, and incorporate all necessary characteristics of the family which affect the translation of gross incomes into disposable incomes. For those not in the labor market the essential step is the estimation of hourly wages which is necessary for the computation of their in-work incomes. In the context of family-related policies many of the determinants of the budget constraint may be assigned to the "institutional context" of family-related decision making. These include family related tax and benefit regulations or the cost of childcare. There has been a significant number of advancements in terms of the way the budget constraints are modeled in the analysis of the labor market. These address various potential cultural or institutional constraints individuals may face. Such extensions, by lowering the deviation between simulated and actual budget constraints, produce more realistic forms of models and help to reduce the potential bias on the estimated preferences. The principal extensions of the simplest approach as summarized in equation (3) are described in more detail in Sections 4.1 and 4.2. Further developments of the model which go beyond modifications of the budget constraint and address specific constraints on individual choices are discussed in Section 4.3. 


\section{$4 \quad$ Family structure and labor market choices - extensions of the static model}

\subsection{Costs of work - children and the budget constraint}

Although in the simple static context we cannot analyze decisions concerning changes in the family structure, one can still examine the implications of family composition on labor market choices, and analyze a large range of family-related policies. An important element of research in this area has been the approach to modeling of costs of work. In many standard applications these have been modeled as fixed cost of taking-up employment, such as the costs of travel to work or costs of work-related clothing. Such approach implies the following change in the expression of the budget constraint:

$$
\begin{gathered}
c_{i}=\gamma\left[y_{f}+y_{m}+y_{s}+w_{f}\left(T-l_{f}\right)+w_{m}\left(T-l_{m}\right)-k_{f}-k_{m}\right] \\
k_{j}=0 \text { if } l_{j}=T \\
k_{j}>0 \text { if } l_{j}<T
\end{gathered}
$$

where $k_{f}$ and $k_{m}$ are the fixed costs of work of women and men, respectively.

Clearly one of the most important costs of working in the case of families with children is the cost of childcare. This could be modeled as a fixed cost of work, i.e. like in equation (4). A more realistic approach, however, relates the costs of work fully or partially to the extent of working time of the parents. Assuming a proportional relationship between the cost of childcare and hours of work, this would translate into the following expression of the budget constraint:

$$
c_{i}=\gamma\left[y_{f}+y_{m}+y_{s}+w_{f}\left(T-l_{f}\right)+w_{m}\left(T-l_{m}\right)-\lambda\left(\left(T-l_{f}\right),\left(T-l_{m}\right)\right)\right]
$$

where $\lambda$ is a childcare cost function related to the intensity of work of both parents. This extension, which accounts for an important cost of work faced by parents, allows not only for a more realistic modeling of their budget constraint, but also facilitates the analysis of policies related to the costs of childcare, such as childcare subsidies or changes in the availability of public childcare. 


\subsection{Benefit non take-up - the costs of stigma}

An important element of the budget constraint is a set of benefits that the family may receive from the government. These may take the form of universal benefits which are independent from the level of income, or may relate to the financial situation of the family and be thus means-tested. In the latter case a well documented fact is imperfect take-up of benefits. This may be an effect of costs of claiming benefits such as the cost of applying to receive them and the complexity of the application procedures, or may result from the stigma effect of benefit claims. In the latter case the cultural context will of course be the natural reference in explaining the phenomenon. The consequence of benefit non-take-up is that actual incomes of families are lower than the incomes modeled in the estimation, and as a result the estimated preferences will be biased. On top of that, any reform to the benefit system ought to take into account its implications for benefit take-up as this may significantly change the budget constraints and thus the effects of the policy.

The effect of non take-up on the budget constraint could be represented in the following way:

$$
\begin{aligned}
& c_{i}=\gamma\left[y_{f}+y_{m}+y_{s}+w_{f}\left(T-l_{f}\right)+w_{m}\left(T-l_{m}\right)\right]-b^{*} \text { if } b=0 \\
& c_{i}=\gamma\left[y_{f}+y_{m}+y_{s}+w_{f}\left(T-l_{f}\right)+w_{m}\left(T-l_{m}\right)\right]-\eta(b) \text { if } b=b^{*}
\end{aligned}
$$

where $\left(b^{*}\right)$ represent the theoretical value of benefits implied by the theoretical function $\gamma$ (and thus included in the $\gamma[$.] expression), and $(b)$ are the actual benefits claimed by the couple. $\eta(b)$ are the stigma costs related to claiming the $\left(b^{*}\right)$ value of benefits. One approach to modeling of non-take up relies on estimating the expected proportion of benefits claimed by a specific type of family using take-up probability models (e.g. Bingley and Walker, 1997a; Myck and Reed, 2006). Another approach used for example in Brewer et al. (2006) uses explicit modeling of benefit take-up which estimates the utility cost of claiming benefits. In the context of benefit take-up one should also stress that its degree, and as a result the estimated parameters of the take-up model, will also be a function of 
individual choices and the cultural context within which they are made. Take-up models may therefore capture some aspects of the cultural context.

\subsection{Limiting choices - unemployment and disability}

The standard static model presented in equation (1) is a strict model of labor market choices. The principal assumption of the model - regardless of how it is estimated - is that individuals (or in our case couples), given their preferences concerning leisure and consumption at time $(t)$ make their optimal choice with regard to the intensity of work they perform, and this choice is what we observe in the data. As we already discussed the identified parameters of these preferences will represent a combination of the true individual valuations and other factors such as those related to the "cultural" and "institutional" contexts within which individuals make their decisions. In addition to this, however, one has to bear in mind that for a significant proportion of the population the observed outcome is not, strictly speaking, a result of unconstrained choice. This relates in particular to the issue of unemployment and health or disability.

There has been a number of approaches to deal with the issue of the constrained part of the population. Most frequently this part of the sample is simply excluded from the estimation usually on the basis of individual declarations of labor market status, defined in most cases by labor market search activity and the willingness to take up a job. Similarly the disabled population is also usually excluded from the analyzed sample.

While such approach can be justified from the point of view of the underlying theory, which assumes unconstrained choices, one has to remember that the implication of such approach is on the one hand ignoring an often large proportion of the population, and on the other introduction of a potentially important sample selection bias. The problem concerning the treatment of constrained populations in our context is the issue of finding the necessary information which would distinguish them from the unconstrained but which at the same time would be independent from the financial incentives we want to model and identify separately. Different approaches have been taken in the literature to identify the constraining factors. 
With respect to unemployment the seminal work of Blundell, et al. (1988) suggested a double-hurdle approach and modeled the probability of rationing of females on the labor market. In an estimation of a linear hours of work equation the authors used a set of labor demand variables across region and time (month of the year) to identify labor market constraints. The labor demand variables included regional age-specific unemployment rates as well as regional vacancy rates. A similar approach using more time variation by estimating the model on several years of data is taken in Blundell et al. (1998). Since then the identification strategy used in these two studies has been taken up in applications of the discretised model, for example in Bingley and Walker (1997b). More recently Bargain et al. (2010) use regionally defined "cluster"-level unemployment rates and individual-level unemployment history information to differentiate between the demand factors driving unemployment and the supply factors affected by financial incentives. What is interesting in the results of Bargain et al. (2010) is the fact that the bias on labor supply predictions is small when the authors simulate policies focused on the unconstrained population. However, the bias becomes substantial in simulations of policies affecting the constrained population. We discuss the estimation aspects of this approach in Section 4.4.

Some light on the importance of employment and health can be shed by approaches which refrain from imposing a strict theoretical structure on the estimation. Examples of such analysis are for example Disney et al. (2006), Myck and Reed (2006), Kalwij and Vermeulen (2008) or Haan and Myck (2009). These approaches do not specifically identify the constraints but extend the standard approach by either detailed approach to modeling of financial incentives among the disabled (Myck and Reed, 2006) or estimate the role of health in determining labor market outcomes. In Haan and Myck (2009) the authors account also for the endogeneity of health and employment, an important element in modeling of labor market dynamics of pre-retirement population. While health constraints have been demonstrated to be of significant influence on labor market behavior, they seem to be of much greater importance in the modeling of older groups of the population and are probably less influential in the estimation of labor market activity of families with children. 
At this point it is also important to note, that a potentially important part of the population which, on the basis of the unemployment definition, is assigned to the unconstrained group, is in fact significantly limited in their choices. This brings us back to the issues of "cultural" and "institutional" contexts of decision making and the interpretation of the estimated preference parameters. Both cultural factors, such as for example the perception that mothers should stay at home, and institutional ones, such as difficulties of parents to find suitable jobs are in fact also constraints on the choices individuals make. These constraints, however, may not be easily identifiable in the data, since many of such individuals would declare their labor market status to be "taking care of home and family". Such imprecise identification of the unconstrained population has important consequence for the interpretation of the estimated models and for the precision of simulated policy effects. If the models assume non-employment of a certain proportion of individuals to be an outcome of their choice, while in fact it is a result of existing constraints, the estimated labor supply elasticity will be downward biased. On the other hand since simulations of policies assume that this part of the population is unrestricted, any simulated changes to financial incentives to work will apply to a larger non-employed population relative to that which in fact would be affected by the changes. The combination of these two potential errors implied by the assumption of the unrestricted choice will determine the degree of potential errors in policy simulations.

\subsection{Moving from static to dynamic considerations}

The discussion in the previous Section focused on the static approach to modeling choices on the labor market. This assumes within period optimization, and thus allows for analysis of labor market choices at a given point in time conditional, among other things, on the family structure. It is a tool which has been widely used to analyze the effect of tax and benefit reforms on the response to changes in financial incentives to work, and in the context of family policy on the effects of tax and benefit reforms on such outcomes as labor market participation of parents, childcare use, and child poverty. ${ }^{5} \mathrm{~A}$ large number of studies used

\footnotetext{
${ }^{5}$ See e.g.: Beblo et al. (2005), Brewer et al. (2006), Dearing et al. (2007), Haan and Myck (2007), Immervoll et al. (2006), Immervoll et al. (2011), Spiess and Wrohlich (2008), Steiner and Wrohlich (2004), Steiner and Wrohlich (2008), Wrohlich (2011).
} 
this framework to analyze reforms related to the goals of increasing employment and reducing poverty - objectives which, as we mentioned in the introduction, may imply policies which would counteract each other. The static model, however, cannot give any specific direct answer on the effect of family-related policies on the decisions of how many children to have and when. In this section we discuss how such decisions could be incorporated into a more general economic model and what other considerations enter the picture once we consider a dynamic decision-making process.

\subsubsection{Determinants of choices in the dynamic context}

In what follows we simplify the anyhow complex structure of the problem by assuming away partnership decisions and maintaining the context of the unitary framework, where a couple maximizes its utility function $U_{i}$. We present a framework often used in empirical applications where to ensure solution and tractability it is assumed that utility is intertemporally separable. This implies that only levels of utility at time $t$ have an impact on the allocation of leisure and consumption at time $(t+s)$. The combination of leisure and consumption which leads to a given utility level at time $t$ is assumed to be irrelevant for the choice at time $(t+s)$. This gives the following expression for the utility function of couple $i$ at time $t$ :

$$
U_{i t}=U\left(U^{t}\left(c_{i t}, l_{m t}, l_{f t}, x_{i t}\right), U^{t+1}\left(c_{i t+1}, l_{m t+1}, l_{f t+1}, x_{i t+1}\right), \ldots ., U^{\tau}\left(c_{i \tau}, l_{m \tau}, l_{f \tau}, x_{i \tau}\right)\right)
$$

where $x_{i t}$ stands for the family structure of family $(i)$ at time $(t)$. This structure will on the one hand have a direct effect on utility, but since it will change in time it will also imply changes in the valuation of leisure and consumption by the couple. At each point in time utility depends now not only on leisure and consumption of each partner, but also directly on the number of children and their characteristics $x_{j}$ such as age or gender. The dynamic nature of the problem, and the dynamic relationship of the different items that enter the utility function expand the number of dimensions which need to be considered to understand the choice concerning labor market participation and fertility at each point in time. The choice at 
each point will be determined by the intertemporal budget constraint that the couple is facing, represented by a time path of assets:

$$
A_{i t+1}=\left(1+r_{t+1)}\right)\left(A_{i t}+\gamma_{t}\left[y_{i t}+w_{m t} h_{m t}+w_{f t} h_{f t}\right]-c_{i t}\right),
$$

Where:

$A_{i t+1}$ is the real value of assets at the beginning of period $t+1$,

$r_{t+1}$ is the real return on assets,

$y_{i t}$ represents unearned-non-asset income (i.e. in terms of equation (3) $y_{i t}=y_{f t+} y_{m t+} y_{s t}$ ),

$h_{m t}=T-I_{m t}$ and $h_{f t}=T-I_{f t}$

$\gamma_{t}$ - is the general tax and benefit function at time $t$.

Without going into the details of the choices implied by this dynamic optimization it is important to discuss the implication of this dynamic nature from the point of view of the discussion of the relationship of fertility and employment. For example the decision to have a child at point $(t+s)$ will need to take into account the following considerations:

a. the child will have a direct effect on parents' utility from $(t+s)$ onwards;

b. having a child will imply direct costs over the time when the child remains dependent on the parents; these costs will be part of household consumption - these may be direct costs of food and clothing or indirect ones, like higher rent or mortgage in the case of adjustment to living conditions;

c. having a child will in the first years of the child's life be likely to reduce the parents' work intensity and thus directly affect earnings;

d. having a child will also significantly change the household life-time budget set: on the one hand there will be negative consequences relating to career changes or wage effects induced by reductions in work experience following family-related breaks in employment (see e.g.: Denkmeyer, 1996; Even, 1987); on the other hand the tax and benefit function $\gamma_{t}$ is likely to include family-related benefits and/or tax advantages which will increase the family budget set; the budget set will also change due to childcare costs (see Immervoll and Barber, 2005, and Wrohlich, 2011).

Many crucial assumptions are embedded in the approach outlined above. First of all thinking of family structure in this way - a framework largely due to the seminal work of Gary Becker (1991, 1992; see also: Becker and Lewis, 1973) - assumes rational choices of the parents, not only concerning their current leisure and consumption, but also concerning the number and timing of children. As pointed out by many authors this in many cases may not be a correct 
assumption (White and Klein, 2008). For example, the frequency of unplanned child births by married women has been quoted as high as 35\% in the US in 2002 (Hayford and Guzzo, 2010). Such "rational" approach may also underappreciate the extent to which families are limited by health-related constraints concerning the ability to conceive and give birth.

The assumption on the rationality of family and labor market choices implied by the approach in equation (8) heavily relies also on parents' knowledge not only concerning their future earnings path and the relationship of earnings and employment opportunities conditional on family composition, but also about the relationship between family composition and disposable income implied by the tax and benefit function $\gamma_{t}$. Parents will thus need to have expectations concerning both their wages and any future changes in family related policy which will affect their disposable incomes. The decisions will also need to take into account expectations and potential changes in the broad institutional context, such as the extent of parental leave and availability and cost of childcare, the cost of education, etc. While the cultural context is probably less prone to change, societal changes and expectations regarding them may also play a role in the dynamics of family life and an optimal approach to childbearing and employment. Naturally any uncertainty that concerns individual expectations would also need to be considered in the analysis of their choices.

The model specified above, despite its complexity, has been extremely useful in demonstrating some key aspects of the relationship between labor market and fertility decisions. For example it follows from the model that individual wages may have both positive and negative effects on the "demand" for children. On the one hand higher parental wages increase demand for children through the income effect - richer parents may want to have more children. On the other hand, higher wages may imply greater opportunity cost of children if they become a constraint on labor market choices. The level of parental wages may also determine the generosity of potential tax advantages related to children, and children may make the family eligible to benefits otherwise unavailable to the parents. Thus parents will have to consider the overall net effect of financial advantages and disadvantages of an additional child. 
Thus even the simplest case of the dynamic approach to the combination of labor market and fertility choices involves a substantial increase in the complexity of the problem. This problem would of course have additional layers of complications if we extended it to include partnership choices and issues related to savings and retirement. As we show in Section 5 below, the actual estimation approaches to modeling of labor market choices and fertility decisions, while being consistent with the implications of the general set up in equations (8) and (9), can be significantly simplified. Following Keane and Wolpin (2002) many studies adopt a flexible specification of a first order Markov model to estimate the life-cycle behavior with respect to employment and fertility. We describe this approach and the requirements it places on research infrastructure in Section 5.4 following a more general approach to estimation of discrete labor supply models.

\section{Estimating the models - empirical approaches to the identification of determinants of parental choices.}

In this section we document how the most popular approach to modeling of labor market and family related choices has developed and has been used in the economic literature. In Section 3.1 we outline the most common approach to modeling labor market decisions and stress the role of microsimulation models as key resources for this purpose. We particularly emphasize identification issues involved and the resulting requirements with respect to socio-economic data that are key to the estimation of such models.

\subsection{Discrete choices on the labor market - the basic static model of labor market choices}

In this section we describe the labor supply model as developed in the seminal work of van Soest (1995) and Aaberge et al. (1995). These studies where among the first to present discrete models of a joint labor supply of both partners in couple households and have been applied in a large number of studies in many countries (see Appendix 1 for details). ${ }^{6}$

\footnotetext{
${ }^{6}$ See also the survey articles by Creedy and Duncan (2002), Creedy and Kalb (2005) and Aaberge et al. (2006).
} 
One very important feature of these models is that labor supply is treated as a discrete choice problem. This means that instead of estimating the participation decision and hours of work as a continuous variable, the decision is made over a discrete number of hours categories. This form of modeling takes into account the fact that hours of work are usually heavily concentrated at particular hours points (in Germany e.g. at 0, 15, 20 and 40 for women and 40 for men; see Steiner and Wrohlich, 2004), which cannot be adequately approximated by a continuous hours distribution. Moreover the specification of a relatively small number of hours categories leads to a significant reduction in the computational burden of calculating the potential net household income at each possible hours choice. The discrete approach also simplifies the treatment of non-employment which can be easily incorporated into the framework as one of the discrete hours options, and does not have to be treated as a specific "corner solution".

In the static framework presented in Section 3.1 the household's labor supply decision is modeled by a utility function (1) which is assumed to depend on the leisure time of the male $\left(I_{m}\right)$ and the female $\left(I_{f}\right)$ spouse as well as on household consumption $\left(c_{i}\right)$, which in the static model is equal to the net household income $\left(y_{i}\right)$. The household's utility index for a particular hours category, $k$, is often modeled by the following translog function:

$$
U_{k}\left(x_{k}\right)=x_{k}^{\prime} A x_{k}+\beta^{\prime} x_{k}+\varepsilon_{k}
$$

where $x=\left(y_{i}, I_{\mathrm{m}}, I_{\mathrm{f}}\right)^{.} .{ }^{7}$ The components of $x_{k}$ are the (natural) logs of net household income, leisure of the husband and the wife, respectively. These components usually enter the utility function (9) with linear, quadratic and cross terms between the spouses' leisure terms and household income. The matrix $A$, with elements $\alpha_{i j}$ (where the $j$ subscript identifies the three elements of $x$ ), contains the coefficients referring to the non-linear terms, while the vector $\beta_{j}$, the corresponding coefficients of the linear terms. $\varepsilon_{k}$ is a stochastic error term accounting for factors affecting the household's utility other than leisure and income. The distribution of this error term will be specified below.

\footnotetext{
${ }^{7}$ Other functional specifications of the utility function, such as linear or linear-quadratic, can also be found in the literature.
} 
The requirements of economic theory with respect to the utility index are that it should be concave in household income and, for given household income, be increasing in both spouses' leisure time (provided working hours were initially positive). Moreover, the first derivative of the utility index with respect to leisure should, ceteris paribus, be positive for both spouses, provided leisure is a normal good, while the second derivative is expected to be negative. These requirements relate to the principle of diminishing marginal utility of leisure and consumption and can imply empirically testable hypotheses.

Given the assumption of the unitary model concerning maximization of a household utility function, the household is assumed to choose hours category $k$ if, in probability terms, the associated utility index, $U_{k}$ exceeds the utility in any other possible alternative $I$, i.e.:

$$
P\left(U_{k}>U_{l}\right)=P\left(\left(x_{k}{ }^{\prime} A x_{k}+\beta^{\prime} x_{k}\right)-\left(x_{l}{ }^{\prime} A x_{l}+\beta^{\prime} x_{l}\right)>\varepsilon_{l}-\varepsilon_{k}\right)
$$

To facilitate the estimation of the model we need to specify the distribution of the stochastic component of the utility function, i.e. $\varepsilon_{k}$. The most common approach is to assume that $\varepsilon_{k}$ is distributed identically across all hours categories according to an extreme-value distribution, implying that the difference of the utility index between any two hours categories follows a logistic distribution. Under this distributional assumption the probability of choosing alternative $k$ relative to alternative $I$ can be described by the conditional logit model, which specifies the probability described by equation (10) as:

$$
P\left(U_{k}>U_{l}\right)=\frac{\exp \left(x_{k}^{\prime} A x_{k}+\beta^{\prime} x_{k}\right)}{\sum_{m} \exp \left(x_{m}^{\prime} A x_{m}+\beta^{\prime} x_{m}\right)}, \forall l \neq k
$$

where the summation sign is defined over all possible alternatives $(m)$, i.e. the specified hours categories.

As we stressed in Sections 3 and 4 different households will not only face different budget constraints given their earning potential and demographic composition, but will also exhibit different preferences with respect to consumption and leisure. With respect to observable 
characteristics this can be accounted for in the model by specifying the parameters $\beta_{m}$ as functions of these variables. Such approach will then capture the differences in preferences for example between better and worse educated individuals or between those with and without children.

As we noted earlier a number of characteristics which determine these preferences will not be observed but several approaches have been developed to account for their potential effect on the estimates of preferences. Accounting for this unobserved heterogeneity allows for capturing the distribution of preference parameters and may be useful in trying to identify "types" of households with respect to their preferences which go beyond the observed characteristics. The approaches which account for unobserved heterogeneity in static labor supply models have another technical advantage in that they relax the restrictive assumption of the independence of irrelevant alternatives (see Haan, 2010, Pacifico, 2010 and Haan et al., 2012 for an overview).

The data requirement for the estimation of the static model outlined above is first of all a representative micro-level dataset which includes detailed information on socio-economic characteristics of households, working hours and gross wages and other income sources. Moreover, since the estimation relies on a detailed calculation of net household incomes for each of the hours categories the dataset needs to be combined with a microsimulation model which contains all the necessary information to model the $\gamma$ function representing the tax and benefit system in a given country. Such models depict all relevant regulations regarding income taxation, social security contributions and all major transfers including child related transfers and means-tested benefits. To translate the observed choices of households into estimates of their preferences, gross incomes resulting from work intensity implied by each of the combinations of hours need to be translated into net household incomes through the $\gamma$ function. Knowing income levels corresponding to each of the categories of hours for every household in combination with the observed choice of hours worked, we can specify the preferences of these households. 


\subsection{Including the costs of work and non take-up in the estimations}

As we noted in Section 4.1 in some applications, typically in those focusing on labor supply of mothers with young children, childcare costs are an important part of the household budget constraint. Accounting for childcare costs on the one hand improves the estimation, and on the other extends the range of policies one can model by facilitating simulations of alternative childcare policies. Similarly, since many types of benefits are not taken up by all families who are eligible to them, accounting for imperfect take-up is also essential from the point of view of accurate identification of incentives faced by the families.

The variation in childcare costs is either captured by the variation in prices of childcare facilities by region or by making use of the differences in childcare expenses across households. In the latter case, childcare costs have to be estimated for households who are not using child care. This is similar to the issue related to the estimation of wages for individuals who are not employed and thus have no wage information in the data.

Costs of childcare, however, are usually only one dimension that affects labor supply of mothers, with availability of childcare places being an important aspect in particular in the countries of continental Europe. From the point of view of the demographic typology the constraints related to availability of childcare constitute an important element of the institutional context. Modeling availability or rationing of childcare is challenging because for most countries, individual-level data on access to subsidized or public childcare is not available. $^{8}$ Thus, availability of childcare has to be simulated or estimated and authors have proposed different ways to incorporate rationing of childcare. While most approaches rely on restricting the choice set according to direct information from the data by estimating the rationing probabilities (e.g. Lokshin, 2004; Kornstad and Thoresen, 2007; Del Boca and Vuri, 2007), Wrohlich (2011) suggested to incorporate rationing of subsidized or public child care in the households' budget constraint. There, it is assumed that rationing occurs only with

\footnotetext{
${ }^{8}$ One exception is Norway. In a study on Norwegian Data, Kornstad and Thoresen (2007) know exactly what families are restricted with respect to access to public childcare.
} 
respect to subsidized child care, not with childcare on the "private market", i.e. child care by nannies or babysitters.

The way modeling of imperfect take-up of benefits has been approached for example in Brewer et al. (2006) specifically used the information observed in the data on whether families eligible to the benefit in question (in their case the Family Credit/Working Families Tax Credit) reported the receipt of the benefit or not. In the estimation procedure each family with eligibility to the benefit is modeled as making an explicit choice of claiming the benefit. This in turn allows for a utility representation of the cost of claiming benefits.

\subsection{Estimating labor supply models accounting for labor market constraints}

One of the limitations of the estimations of the static model we discussed above is that it does not account for potential constraints affecting the availability of assumed choice options. In Bargain et al. (2010) the authors combine the estimation of the discrete model to account for labor market constraints. This is done in the form of a double-hurdle approach, where the first choice is a voluntary decision on whether to participate in the labor market, while the second hurdle concerns the probability of being rationed in the labor market conditional on the willingness to participate in the first stage. Using the notation of Bargain et al. (2010) an individual can be:

- $\quad$ voluntarily inactive with zero desired hours $d$ for whom we estimate the probability: $\operatorname{Pr}\left(d_{i}=0\right)$;

- $\quad$ rationed, involuntarily unemployed, with desired hours $d>0$ and the probability of being non-rationed, $p=0$, for whom we estimate the probability: $\operatorname{Pr}\left(d_{i}>0, p_{i}=0\right)$;

- $\quad$ non-rationed and working, with desired hours $d>0$ and the probability of being nonrationed, $p=1$, for whom we estimate the probability: $\operatorname{Pr}\left(d_{i}>0, p_{i}=1\right)$;

Since in the case of rationed individuals we do not observe their hours of work Bargain et al. (2010) use their declared desired hours as the choice they would make if they were not rationed. The estimation approach follows the general method of Section 5.1 with the hours choice probabilities appropriately adjusted for being or not being rationed. 
In a similar way also Aaberge et al. (1995) have modeled hours restrictions. The authors specify a probability density function of discrete hours points for each individual. The discrete choice set used in the estimation is built by sampling from that individual specific density function. The paper by Aaberge et al. (2009) summarizes findings from models with and without taking into account hours constraints.

\subsection{Estimating dynamic labor supply models and models with endogenous fertility}

As explained already in Section 3, static models of labor supply have several shortcomings from a theoretical and an empirical point of view. First of all, they rely on the restrictive assumption that individuals are myopic. In dynamic models of labor supply, one can account for the fact that people might make choices today knowing that these will have consequences on their welfare in the future. Another reason in favor of using dynamic structural models of labor supply is to be able to relax the assumption that other choices, in particular fertility decisions are exogenous with respect to labor market and consumption choices.

The standard approach of static labor supply models outlined above cannot be used to evaluate policy reforms with respect to fertility choices. Moreover, potential feedback effects that labor market preferences might have on fertility also cannot be captured. Thus, in order to evaluate policy reforms with respect to these issues, one needs an intertemporal model of labor supply, fertility and childcare choices.

The estimation of such models imposes much greater demands with respect to the data which can be used for this purpose in comparison to static labor supply models. While the latter can be estimated on cross-sectional data, in order to estimate dynamic structural models (e.g. Francesconi, 2002) one needs longitudinal data, i.e. information on households over a number of consecutive years. The usual requirement to identify the basic dynamic models is to have information over three years of data, but for identification of heterogenous cohort effects even longer observation periods are required. 
In the literature on labor supply and fertility decisions, models range from reduced form static specifications which treat the employment and fertility decision separately to dynamic structural life cycle models where women maximize life cycle utility and jointly determine their optimal behavior, e.g. Francesconi (2002). Keane and Wolpin (2002) show that a first order Markov model which captures intertemporal state dependence effects serves as a good approximation of the predicted optimal fertility and employment behavior over the life-cycle. Following this, a number of recent studies have adopted a flexible specification of a first order Markov model to estimate the life-cycle behavior with respect to employment and fertility. An important issue in this context is identification of determinants of fertility choices. In earlier papers such as by Francesconi (2002), Del Boca and Sauer (2009), the identification is based on functional form assumptions. Another approach is taken by Carrasco (2001) and Michaud and Tatsiramos (2008) who use the sex composition of siblings as an exclusion restriction. This approach, however, restricts fertility choices to choices about whether or not to have a third child. Yet a different approach is used by Laroque and Salanie (2004 and 2008) and Haan and Wrohlich (2011) who explicitly use an identification strategy that relies on the variation in the tax and transfer system and childcare institutions induced by changes in female wages, in non-labor income including the partner's wage, other household characteristics such as marital status and in particular by changes in the fiscal institutions over time. This variation can be exploited to estimate the sensitivity of fertility and employment with respect to financial incentives. With these models, it is possible to simulate social policy reforms and predict behavioral responses not only with respect to labor supply but also with respect to fertility decisions.

\section{Conclusion}

In this paper we have focused the discussion on the theory and practice of joint analysis of family and labor market policies. Drawing on examples from the literature we have discussed the most frequently used economic estimation approach based on microsimulation which has been set in the context of most relevant demographic approaches to the analysis of fertility and employment. We demonstrated the challenges that face researchers and policymakers in the identification of causal effects of policies on 
fertility and labor market choices. Understanding the causal paths between these is crucial from the point of view of ex-ante assessment of family-related policies. We argued that while the economic approach cannot address all aspects of the decision making process with regard to fertility and the labor market, modeling based on detailed micro-level data sets can provide a firm basis for interpretation of the driving factors behind these decisions, and importantly can identify causal effects of policies on a number of crucial aspects of family life.

The discussion in this paper focused on the microsimulation approach to modeling of labor market and fertility decisions. We have documented the ample scope of applications of this method and demonstrated its usefulness in several important policy areas. It is clear that the method to be an effective evaluation approach requires very detailed micro-level data to be available to researchers. The more questions one wants to answer, the more detailed and comprehensive is the required data infrastructure. Examples of countries where such data has been collected and made available to researchers, like Germany or the UK, show that careful evaluation of policies can lead to improvements in the quality of introduced reforms and evidence-based modifications. As we pointed out in the discussion only two out of the three policy objectives - employment and child poverty - can be analyzed using crosssectional data. If research is to inform policy debate concerning fertility decisions then rich data including labor market and incomes information needs to be collected in the longitudinal format to follow families through time and observe changes in family composition. In addition to information on demographics and income the data sets should also contain specific details on household expenditures, in particular concerning childcare use and childcare expenses.

On top of the crucial issue of data availability, to assess family and labor market related policies researchers need to continue to develop detailed research tools to be able to model tax and benefit systems within which the families operate. As we have shown in the paper, any structural analysis linking choices on the labor market and those regarding family formation requires the ability to model the financial consequences of the entire set of choices that the families have at their disposal. Microsimulation models are essential for such an exercise. 


\section{References:}

Aaberge, R.., J.K. Dagsvik and S. Strøm (1995): Labor Supply Responses and Welfare Effects of Tax Reforms, Scandinavian Journal of Economics, 97, 4, 635-659.

Aaberge, R., Colombino, U. and S. Strøm (1999): Labor Supply in Italy: An Empirical Analysis of Joint Household Decisions, with Taxes and Quantity Constraints, Journal of Applied Econometrics 14, pp. 402-422.

Aaberge, R., Colombino, U. and T. Wennemo (2009): Evaluating Alternative Representations of the Choice Sets in Models of Labour Supply, Journal of Economic Surveys, 23(3), pp.407-612.

Anderson, P.M., and P.B. Levine (1999): "Child Care and Mothers' Employment Decisions," NBER Working Paper No. 7058, Cambridge, MA.

Bargain, O. and K. Orsini (2006): In-Work Policies in Europe: Killing two Birds with one Stone?, Labour Economics 13 (6), pp. 667-693.

Bargain, O., M. Beblo, D. Beninger, R. Blundell, R. Carrasco, M.C. Chiuri, F. Laisney, V. Lechene, E. Longobardi, N. Moreau, M. Myck, J. Ruiz-Castillo, and F. Vermeulen (2006): Does the representation of the household behavior matters for welfare analysis of taxbenefit policies? An introduction, Review of the Economics of the Household, Vol. 4., pp. 99-111.

Bargain O., M. Caliendo, P. Haan, and K. Orsini (2010): Making Work Pay in a Rationed Labor Market, Journal of Population Economics Vol. 23/1, pp. 323-351.

Beblo, M., C. Lauer and K. Wrohlich (2005): Ganztagsschulen und die Erwerbstätigkeit von Müttern. Eine Mikrosimulationsstudie für Deutschland, Zeitschrift für Arbeitsmarktforschung - Journal for Labor Market Research, Vol 38/2+3, pp. 357-372.

Beninger, D., Bargain, O., Beblo, M., Blundell, R., Carrasco, R., Chiuri, M.C., Laisney, F., Lechene, V., Longobardi, E. Moreau N., Myck, M., Ruiz-Castillo, J., Vermeulen, F. (2006) " Evaluating the move to a linear tax system in Germany and other European countries", Review of the Economics of the Household, vol. 4., pp. 159-180.

Becker G.S. and H. Gregg Lewis (1973): "On the Interaction between the Quantity and Quality of Children". The Journal of Political Economy 81: pp. 279-288.

Becker, G.S. (1991): A Treatise on the Family, Harvard University Press.

Becker, G.S. (1992): Fertility and the economy, Journal of Population Economics, 5, pp. 185201.

Becker G.S. and H. Gregg Lewis (1973): "On the Interaction between the Quantity and Aaberge, R., . Dagsvik and S. Strom (1995): Labour Supply Responses and Welfare Effects of Tax Reforms, Scandinavian Journal of Economics Vol. 97/4, pp. 635-659.

Bingley P. and I. Walker (1997a): "Labour supply and in-work and in-kind transfers," IFS Working Papers W97/02, Institute for Fiscal Studies. 
Bingley, P. and I. Walker (1997b): "The Labour Supply, Unemployment and Participation of Lone Mothers in In-Work Transfer Programmes," Economic Journal, Royal Economic Society, Vol. 107(444), pp. 1375-90, September.

Blau, D. and A. Hagy (1998): The Demand for Quality in Child Care, The Journal of Political Economy Vol. 106/1, pp. 104-146.

Blossfeld, H-P. (1995): Changes in the process of family formation and women's growing economic independence: A comparison of nine countries. In H.-P. Blossfeld (Ed.), The new role of women: Family formation in modern societies, pp. 3-23. Boulder, CO: Westview Press.

Blossfeld, H.P. (1996): Macro-sociology, rational choice theory, and time: A theoretical perspective on the empirical analysis of social processes, European Sociological Review, 12, pp. 181-206.

Blundell, R. (2001): Welfare reform for low income workers, Oxford Economic Papers 53, pp. 189-214.

Blundell, R., F. Chiappori, and C. Meghir, (2005): Collective Labor Supply with Children, Journal of Political Economy, 113, No. 6.

Blundell, R., A. Duncan, J. McCrae and C. Meghir (2000): The Labour Market Impact of the Working Families' Tax Credit, Fiscal Studies 21/1, pp. 75-104.

Blundell, R., J. Ham, and C. Meghir (1998): Unemployment, discouraged workers and female labour supply, Research in Economics 52, pp. 103-131.

Blundell, R., C. Meghir, E. Symons and I. Walker (1988): Labour supply specifications and the evaluation of tax reforms, Journal of Public Economics, 36/1, pp. 23-52.

Blundell, R. and A. Shephard (2012): Employment, Hours of Work and the Optimal Taxation of Low Income Families, Review of Economic Studies, forthcoming.

Bargain O. and K. Orsini (2006): In-Work Policies in Europe: Killing Two Birds with One Stone, "Labour Economics", Vol. 13, No. 6, pp. 667-693.

Brewer, M., A. Duncan, A. Shephard, and M.-J. Suarez (2006): “Did Working Families' Tax Credit Work? The Impact of In-Work Support on Labour Supply in Great Britain", Labour Economics 13, pp. 699-720.

Brewer, M. and J. Browne (2006): The effect of the working families' tax credit on labour market participation. Briefing Note 69, Institute for Fiscal Studies, London.

Chiappori, P.-A. (1992): Collective labor supply and welfare, Journal of Political Economy, 100, pp. 437-67.

Duncan, A. and C. Giles (1996): Labour Supply Incentives and Recent Family Credit Reforms The Economic Journal, Vol. 106, No. 434. (Jan., 1996), pp. 142-155.

Carrasco, R. (2001): Binary Choice Models With Binary Endogenous Regressors in PanelData: Estimating the Effect of Fertility in Female Labor Participation, Journal of Business and Economics Statistics, 19, pp. 385-394.

Creedy, J. and A. Duncan (2002): Behavioural Microsimulation with Labour Supply Responses, Journal of Economic Surveys, 16(1), pp.1-39. 
Creedy, J. and G. Kalb (2005): Discrete Hours Labour Supply Modelling: Specification, Estimation and Simulation, Journal of Economic Surveys, 19(5), pp. 697-734.

Cleveland G., M. Gunderson, and D. Hyatt (1996): “Child Care Costs and and the Employment Decision of Women: Canadian Evidence", The Canadian Journal of Economics, 29/1, 132151.

Connelly, R. (1992): "The Effect of Child Care Costs on Married Women's Labor Force Participation," The Review of Economics and Statistics, 74, pp. 83-90.

Dearing, H., H. Hofer, C. Lietz, R. Winter-Ebmer and K. Wrohlich (2007): Why do mothers work longer hours in Austria than in Germany? A comparative microsimulation study, Fiscal Studies Vol. 28/4, pp. 463-495.

Del Boca, D. and R. Sauer (2009): Life Cycle Employment and Fertility Across Institutional Environments, European Economic Review, 53(3), pp. 274-292.

Del Boca, D. and D. Vuri (2007): The Mismatch between Employment and Child Care in Italy: The Impact of Rationing, Journal of Population Economics, Vol. 20/4, pp. 805-832.

Denkmeyer, B. (1996): Long-run opportunity-costs of children according to education of the mother in the Netherlands, Journal of Population Economics, 9, pp. 349-361.

Disney, R., C. Emmerson, and M. Wakefield (2006): III health and retirement in Britain: a panel data-based analysis. Journal of Health Economics, 25 (4), pp. 621-649.

Duncan, A and C. Giles, C (1996): 'Should we subsidise pre-school childcare and, if so, how?', Fiscal Studies, 17 (3), pp. 39-61.

Easterlin, R. A. (2004): The Reluctant Economist. Perspectives on Economics, Economic History and Demography, Cambridge, Cambridge University Press.

Easterlin, R. A. (1976): The conflict between aspirations and resources. Population and Development Review, 2, pp. 417-425.

Easterlin, R. A. (1980): Marriage and childbearing. In R. A. Easterlin (Ed.), Birth and fortune: The impact of numbers on personal welfare, pp. 37-59. New York: Basic Books.

Ermisch, J. F. (1979): The relevance of the 'Easterlin hypothesis' and the 'New Home Economics' to fertility movements in Great Britain. Population Studies, 33, pp. 39-58.

Even, W. E. (1987): Career interruptions following childbirth, Journal of Labor Economics, 5, pp. 255-277.

Fertility, Family Planning, and Reproductive Health of U.U. Women: Data From the 2002 National Survey of Family Growth (2005): Vital and Health Statistics, 23 (25), U.S. Department of Health and Human Services.

Flood, L., J. Hansen, and R. Wahlberg (2004): Household Labor Supply and Welfare Participation in Sweden. Journal of Human Resources, Vol. 39 (4), pp. 1008-1032.

Francesconi, M. (2002): A Joint Dynamic Model of Fertility and Work of Married Women, Journal of Labor Economics, 20 (2), pp. 336-380.

Haan, P. (2010): A Multi-State Model of State Dependence in Labor Supply, Labour Economics, Vol. 17 (2), pp. 323-335. 
Haan, P., D. Kemptner and A. Uhlendorff (2012): Bayesian Procedures as a Numerical Tool for the Estimation of Dynamic Discrete Choice Models, IZA Discussion Paper No. 6544.

Haan, P., and M. Myck (2007): Apply with caution: introducing UK-style in-work support in Germany, Fiscal Studies, Vol. 28, pp. 43-72.

Haan, P. and M. Myck (2009): Dynamics of Health and Labour Market Risks, Journal of Health Economics 28/6, pp. 1116-1125.

Haan, P. and K. Wrohlich (2011): Can Child Care Encourage Employment and Fertility? Evidence from a Structural Model. Labour Economics, Vol. 18 (4) (2011), pp. 498-512.

Hakim, C. (2003): A New Approach to Explaining Fertility Patterns: Preference Theory, Population and Development Review, 29 (3), pp. 349-374.

Hakim, C. (2000): Work-lifestyle choices in the 21st century: Preference theory. Oxford: Oxford University Press.

Hansen, J. and X. Liu (2011): Estimating Labor Supply Responses and Welfare Participation: Using a Natural Experiment to Validate a Structural Labor Supply Model. IZA Discussion Paper No. 5718.

Hayford, S. R. and K. B. Guzzo (2010): Age, relationship, and the planning status of births, Demographic Research, 23, pp.365-398.

Hoynes, H. (1996): Welfare Transfers in Two-Parent Families: Labor Supply and Welfare Participation under the AFDC-UP Program, Econometrica 64/2, pp. 295-332.

Immervoll, H. and D. Barber (2005): Can Parents Afford to Work? Childcare Costs, TaxBenefit Policies and Work Incentives. IZA Discussion Paper No. 1932.

Immervoll, H., H. Levy, C. Lietz, D. Mantovani, C. O’Donoghue, H. Sutherland, and G. Verbist, (2006): Household Incomes and Redistribution in the European Union: Quantifying the Equalising Properties of Taxes and Benefits. In: Papadimitriou, D. B. (ed.), The Distributional Effects of Government Spending and Taxation, Palgrave MacMillan.

Immervoll, H., H. J. Kleven, C. T. Kreiner and N. Verdelin (2011): An Evaluation of the TaxTransfer Treatment of Married Couples in European Countries, Journal of Public Economics, 95 (11-12), pp. 1485-1500.

Kalwij, A. and F. Vermeulen (2008): Health and labour force participation of older people in Europe: what do objective health indicators add to the analysis? Health Economics 17 (5), pp. 619-638.

Keane, M. and R. Moffitt (1998): A Structural Model of Multiple Welfare Program Participation and Labor Supply, International Economic Review 39/3, pp. 553-589.

Keane, M. and K. Wolpin (2002): Estimating Welfare Effects Consistent with Forward-Looking Behavior: Part II: Empirical Results," Journal of Human Resources, 37, pp. 600-622.

Kornstad, T. and T. O. Thoresen (2007): A Discrete Choice Model for Labor Supply and Child Care, Journal of Population Economics, 20 (4), pp. 781-803.

Lalive, R. and J. Zweimuller (2005): Does parental leave affect fertility and return-to-work? Evidence from a 'true natural experiment' (IZA Discussion paper No. 1613). Bonn: Institute for the Study of Labor. 
Laroque, G. and B. Salanie (2004): Fertility and Financial Incentives in France," CESifo Economic Studies, 50, pp. 423-450.

Laroque, G. and B. Salanie (2008): Does Fertility Respond to Financial Incentives?," IZA Discussion Paper, 3575.

Levy, H., L. Morawski, and M. Myck (2009): "Alternative tax-benefit strategies to support children in Poland", in Lelkes, O., Sutherland, H. (eds.) Tax and Benefit Policies in the Enlarged Europe: Assessing the Impact with Microsimulation Models, Ashgate, Vienna.

Liefbroer, A.C. and M. Corijn (1999): Who, what, where, and when? Specifying the impact of educational attainment and labour force participation on family formation, European Journal of Population, 15, pp. 45-75.

Lokshin, M. (2004): Household Childcare Choices and Women's Work Behavior in Russia, The Journal of Human Resources, 39 (4), pp. 1094-1115.

Macunovich, D. (1996): Relative income and price of time: Exploring their effects on U.S. fertility and female labour force participation. Population and Development Review, 22 (Supplement), pp. 223-257.

Matysiak, A. (2011): On the interdependencies between fertility and women's labour supply, European Studies of Population, 17, Springer.

Meghir C. and D. Phillips (2010): Labour Supply and Taxes, in: Adam et. al "Dimensions of Tax Design. The Mirrlees Review", Institute for Fiscal Studies, London.

Michalopoulos, C., P. Robins and I. Garfinkel (1992): A Structural Model of Labor Supply and Child Care Demand, The Journal of Human Resources 27/1, pp. 166-203.

Michaud, P. and K. Tatsiramos (2008): Fertility and Female Employment Dynamics in Europe: The Effect of Using Alternative Econometric Modeling Assumptions," IZA DiscussionPaper, 3853.

Muszyńska, M. (2007): Structural and Cultural Determinants of Fertility in Europe, Warsaw, Warsaw School of Economics.

Myck, M., Bargain, O., Beblo, M. Beninger, D., Blundell, R., Carrasco, R., Chiuri, M.C., Laisney, F., Lechene, V., Longobardi, E. Moreau N., Ruiz-Castillo, J., Vermeulen, F. (2006) "The working families' tax credit and some European tax reforms in a collective setting", Review of the Economics of the Household, vol. 4., pp. 129-158.

Myck, M. and H. Reed (2006): "Tax and Benefit Reforems in a Model of Labour Market Transitions", Vierteljahrshefte zur Wirtschaftsforschung (Quarterly Journal of Economic Research) 75, (3).

OECD - Organization for Economic Cooperation and Development (2001): Balancing Work and Family Life - Helping Parents into Paid Employment, Chapter 4 of the OECD Employment Outlook 2001, Paris.

OECD - Organization for Economic Cooperation and Development (2009): Doing Better for Children, Paris.

OECD (2011): Doing Better for Families, OECD Publishing.

http://dx.doi.org/10.1787/9789264098732-en. 
Olah, L. S. (2003): Gendering fertility: Second births in Sweden and Hungary. Population Research and Policy Review, 22, pp. 171-200.

Pacifico, D. (2010): On the role of unobserved preference heterogeneity in discrete choice models of labor supply, Mimeo, University of Modena \& Reggio Emilia.

Pampel, F. C. and H. E. Peters (1995): The Easterlin effect. Annual Review of Sociology, 21, pp. 163-194.

Powell, L. (2002): Joint Labor Supply and Childcare Choice Decisions of Married Mothers, The Journal of Human Resources 37/1, pp. 106-128.

Prowse, V. L. (2005): State Dependence in a Multi-State Model of Employment Dynamics, IZA Discussion Papers; 1623, Institute for the Study of Labor (IZA), Bonn.

Ribar, D. (1995): A Structural Model of Child Care and the Labor Supply of Married Women, Journal of Labor Economics, 13/3, 558-597.

Rønsen, M. (2004): Fertility and public policies: Evidence from Norway and Finland. Demographic Research, 10, pp. 143-170.

Sjoberg, O. (2004): The role of family policy institutions in explaining gender-role attitudes: a comparative multilevel analysis of thirteen industrialized countries, Journal of European Social Policy, 14, pp. 107-123.

Spiess, C. K. and K. Wrohlich (2008): Parental Leave Benefit Reform in Germany: Costs and Labour Market Outcomes of Moving towards the Nordic Model, Population Research and Policy Review, Vol. 27 (5), pp. 575-591.

Soja, E. (2005): Hipoteza Easterlina w 'swietle zachowa'n prokreacyjnych generacji urodzonych w latach 1942-1966 w Polsce [The Easterlin Hypothesis and the fertility behaviours of cohorts born 1942-1966 in Poland]. Warsaw: Fundacja Promocji i Akredytacji Kierunków Ekonomicznych i Polskie Towarzystwo Ekonomiczne.

Steiner V. and K. Wrohlich (2004): Household Taxation, Income Splitting and Labor Supply Incentives: A Microsimulation Study for Germany, CESifo Economic Studies Vol. 50, pp. 541-568.

Steiner V. and K. Wrohlich (2008): Introducing Family Tax Splitting in Germany: How Would it Affect the Income Distribution, Work Incentives and Household Welfare?, FinanzArchiv, Vol. 64, pp. 115-142.

Todd, Petra and K. I. Wolpin (2006): Using a Social Experiment to Validate a Dynamic Behavioural Model of Child Schooling and Fertility: Assessing the Impact if a School Subsidy Program in Mexico, American Economic Review XXX.

Van Soest, A. (1995): Structural Models of Family Labor Supply: A Discrete Choice Approach, Journal of Human Resources Vol. 30, pp. 63-88.

Van Soest, A., M. Das, X. Gong (2002): A structural labour supply model with flexible preferences, Journal of Econometrics, Vol. 107(1-2), pp. 345-374.

Vermeulen, F., Bargain, O., Beblo, M. Beninger, D., Blundell, R., Carrasco, R., Chiuri, M.C., Laisney, F., Lechene, V., Longobardi, E. Moreau N., Myck, M., Ruiz-Castillo, J. (2006) "Collective models of labor supply with nonconvex budget sets and nonparticipation: A calibration approach", Review of the Economics of the Household, vol. 4., pp. 113-127. 
White, J. M. and D. M. Klein (2008): Family Theories, Sage Publications.

Willekens, F. J. (1991): Understanding the interdependence between parallel careers. In J. J. Siegers, J. de Jong-Gierveld, and E. van Imhoff (Eds.), Female labour market behaviour and fertility: A rational-choice approach, pp. 11-31. Berlin: Springer.

Willekens, F. J. (1999): The life-course approach: Models and analysis. In L. J. G. Van Wissen, \& P. A. Dykstra (Eds.), Population issues. An interdisciplinary focus, pp. 23-51. Dordrecht: Kluwer.

Wrohlich, K. (2007): Evaluating Family Policy Reforms Using Behavioral Microsimulation. The Example of Childcare and Income Tax Reforms in Germany. PhD Thesis, Free University of Berlin.

Wrohlich, K. (2011): Labor Supply and Child Care Choices in a Rationed Child Care Market. DIW Discussion Paper No. 1169. 


\section{Appendix}

\section{Estimating consequences of policies using the microsimulation approach: review of empirical studies}

This Appendix presents a summary of results from studies in the microsimulation literature which deal directly with the impact of policy reforms on labor supply and/or fertility.

Some of the listed papers focused on one or more actually implemented reforms while others on hypothetical reforms or policies discussed in the policy debate. The general idea of most of the simulated hypothetical reforms was to introduce changes that reduce more or less explicit/direct work disincentives that result form original structure and rules of existing tax and benefit systems. The reforms involved changes in general tax rules (Aaberge et al., 1995; Aaberge et al., 1999; Haan 2010; Van Soest, 1995), as well as changes in the tax and benefit rules affecting families from the lower end of income distribution, such as changes of tax free amounts or tax cuts/deductions (Van Soest et al. 2002; Flood et al., 2004; Van Soest, 1995) or changes in benefits or tax credits (e.g. Bargain et al., 2010; Creedy and Kalb 2005; Keane and Moffit, 1998; Bingley and Walker, 1997; Flood, et al. 2004; Hoynes, 1996; Keane and Moffit 1998). Some papers also simulated changes in the minimum wage and wage subsidies (Keane and Moffit 1998; Prowse 2005). Some of the papers considered assessed the impact of reforms referring directly to that aspect of labour supply decision constraints (Laroque and Salanie 2008; Myck et al., 2006; Haan and Wrohlich, 2011; Kornstad and Thoresen, 2007; Lokshin 2004; Michalopoulos et al. 1992; Powell, 2002; Ribar, 1995; Wrohlich 2006). Only four papers involved assessing the impact of policy reforms on fertility (Laroque and Salanie 2004 and 2008; Todd and Wolpin 2006; Haan and Wrohlich 2011).

The reviewed papers deal with different types and variants of policy reforms and were applied to different periods and populations. They thus estimate preferences under different cultural, institutional and economic contexts. Moreover, they used different model specifications, assumptions and estimation methods. Thus the results cannot be easily generalized. However, the overall picture is that generally the direction of the labor force 
response is consistent with the direction suggested by economic theory, but the magnitude of changes ranges form negligible to significant depending on particular simulation. The general picture that emerges from the analysis is the following:

a) shift to proportional taxation and individual taxation increases labor supply, at least in some subpopulations,

b) tax reductions and greater generosity of in-work credits increase the labor supply of first earners but usually have strong negative effects on secondary earners in couples;

c) in-work policies conditional on wages seem more effective in terms of employment effects than those conditional on earnings,

d) subsidizing childcare increases labor supply of mothers,

e) child subsidies unconditional on working of mothers increase fertility,

f) d) introducing care allowances for non-employed mothers reduces the female labor supply.

The list of studies together with an outline of modeled reforms and a description of the main results is presented in Table A1. 
Table A1

Results of policy reforms on labor supply and fertility - summary from the microsimulation literature.

\begin{tabular}{|c|c|c|}
\hline Article & $\begin{array}{l}\text { Country of analysis and simulated } \\
\text { policies }\end{array}$ & Main results \\
\hline $\begin{array}{l}\text { Aaberge, Dagsvik and Strøm } \\
\text { (1995) }\end{array}$ & $\begin{array}{l}\text { Norway: } \\
\text { - } \text { reduction in formal marginal tax } \\
\text { rates (actual reforms introduced } \\
\text { between 1979-1992) } \\
\text { - introduction of proportional taxation } \\
\text { (hypothetical reform) }\end{array}$ & $\begin{array}{l}\text { - (budget neutral) shift to proportional taxation of wage income increases participation rates by } \\
\text { approx. 13,6\% (women) and 6,2\% (men), and increases, given participation, annual hours of } \\
\text { work by } 38 \% \text { (women) and 31\% (males); } \\
\text { the } 1992 \text { tax system compared to the one from } 1979 \text { also has a positive effect on labor supply, } \\
\text { however the effects are much smaller compared to the hypothetical proportional taxation } \\
\text { reform. }\end{array}$ \\
\hline $\begin{array}{l}\text { Aaberge, Colombino and } \\
\text { Strøm (1999) }\end{array}$ & $\begin{array}{l}\text { Italy: } \\
\text { - introduction of proportional tax on } \\
\text { earnings, } \\
\text { - increased progressivity of earnings } \\
\text { taxation }\end{array}$ & $\begin{array}{l}\text { - (budget neutral) shift to proportional taxes has negative effect on female labor supply, and } \\
\text { positive, but weak, impact on male labor supply: strong cross-wage and weak own wage } \\
\text { effects among middle and high income earners are the main reason for the stability in } \\
\text { aggregate labor supply. } \\
\text { - (budget neutral) increased progressivity has a weak negative effect on both female and male } \\
\text { labor supply; }\end{array}$ \\
\hline $\begin{array}{l}\text { Bargain, Caliendo, Haan and } \\
\text { Orsini (2010) }\end{array}$ & $\begin{array}{l}\text { Germany: } \\
\text { - the “mini-job" reform - changes to } \\
\text { special SSC and tax treatment of } \\
\text { lowest earnings } \\
\text { - alternative hypothetical } \\
\text { 'employment bonus' conditional on } \\
\text { wage rate }\end{array}$ & $\begin{array}{l}\text { - the "mini-job" reform found to have a positive effect on participation but negative effect on } \\
\text { hours of work in particular affecting secondary earners (mainly women); } \\
\text { - 'employment bonus' has a strong participation effect and it avoids negative effects at the } \\
\text { intensive margin; }\end{array}$ \\
\hline Bargain and Orsini (2006) & $\begin{array}{l}\text { France, Germany and Finland: } \\
\text { - two types of in-work benefits: family } \\
\text { means-tested working-tax credit } \\
\text { (WTC) and purely individualized low- } \\
\text { wage subsidy (LWS) }\end{array}$ & $\begin{array}{l}\text { - WTC increases single woman participation by about 1,8\% in Germany and Finland and by } \\
0,51 \% \text { in France; it decreases married woman participation by } 1,43 \%, 1,17 \% \text { and } 4,23 \% \text {, } \\
\text { respectively; the net effect on employment is negative in all three countries; } \\
\text { - LWS has a positive effect on the participation of both: single and married woman, the net } \\
\text { effect on participation is } 0,33 \% \text { (single) and 3,1\% (married) in France, } 0,8 \% \text { and } 0,99 \% \text { in } \\
\text { Germany and } 1,17 \% \text { and } 0,34 \% \text { in Finland. }\end{array}$ \\
\hline Bingley and Walker (1997) & $\begin{array}{l}\text { Great Britain: } \\
\text { - hypothetical increases of maximum } \\
\text { values of the in-work Family Credit } \\
\text { (FC) (focus on lone mothers) }\end{array}$ & $\begin{array}{l}\text { - increase in the value of the FC has significant effects on part-time employment and some } \\
\text { effect on the desire to participate; } \\
\text { - essentially no adverse effect on the probability of full-time work; } \\
\text { - doubling the maximum value of FC reduces voluntary non-participation by about } 15,1 \% \text {, } \\
\text { increases involuntary unemployment, and part and full time employment, }\end{array}$ \\
\hline
\end{tabular}




\section{Table A1 continued}

Duncan, McCra and Meghir (2000)

- actual reform replacing family credit with working families' tax credit (WFTC)

Blundell, Shephard (2012) Great Britain:

- 1997 Working Families' Tax Reform (WFTC)

$\begin{array}{ll}\text { Creedy and Kalb (2005) } & \text { Australia: } \\ & -\quad \text { hypothetical reform reducing benefit }\end{array}$
taper rates from $50 \%$ and $70 \%$ to $30 \%$;

Flood, Hansen and Sweden:

Wahlberg (2004) - hypothetical reforms of both tax structure and benefit rules (increase in general tax deductions and reductions in social and housing assistance levels);

\begin{tabular}{|c|c|}
\hline Haan (2010) & $\begin{array}{l}\text { Germany: } \\
\text { - hypothetical shift from joint to } \\
\text { individual taxation of married } \\
\text { couples; }\end{array}$ \\
\hline Haan and Myck (2007) & $\begin{array}{l}\text { Germany: } \\
\text { - hypothetical reform introducing "UK } \\
\text { style" in-work tax credits }\end{array}$ \\
\hline Haan and Wrohlich (2011) & $\begin{array}{l}\text { Germany: } \\
\text { - hypothetical increase in subsidized } \\
\text { public child care compared to } \\
\text { universal child benefit increases }\end{array}$ \\
\hline
\end{tabular}

- (assumption of $100 \%$ take-up) participation rates of single parents increase by approx. 5,5\%

- participation rates of married women with employed partners fall slightly (by $0,84 \%$ ) but for married women with unemployed partners increase by $3,1 \%$

- participation rates of married men hardly change (increase by $0,09 \%$ )

- small increase in overall participation rates

- introduction of WFTC was responsible for over a half of the rise in employment in the period 1997-2002

- changes in the taper increase participation rates of lone parents (by about $8 \%$ )

- overall the average weekly hours of work increase by about 3 hours;

- positive employment effects on families with children;

- combination of reforms results in an increase in hours of work by about $1.1 \%$ for wives and by $0.3 \%$ for husbands.

- the average effects on labor supply are small: only $0.6 \%$ of husbands and $2.0 \%$ of wives change their working hours;

- a relatively strong increase in both wives' (8\%) and husbands' (3\%) hours of work among lowincome households.

- estimation of short and long run effects on participation and hours: fairly high effects on female participation and hours;

- long run results: change in female participation of over $7 \%$ and female hours of work by over $12 \%$;

- employment of single women increases by $2,9 \%$ and single man only by $0,34 \%$; their number of hours worked increases by $2,6 \%$ and $0,31 \%$ respectively;

- the overall effect on employment of men and women in couples is negative but small (less than $1 \%$ decrease of employment and hours worked)

- positive employment effects: participation increases by $1.6 \%$ and working hours by $2.4 \%$.

- no significant overall fertility effects;

- strongest employment and fertility effects on highly educated women without children:

- higher lump-sum child benefits lead to an increase in the fertility rate, but at the cost of lower employment levels; 


\section{Table A1 continued}

Hoynes (1996)

United States:

- evaluation of the Aid to Families with Dependent Children-Unemployed Parent (AFDC-UP) program; and Verdelin (2011)

15 European countries:

- (budget neutral) reforms that reduce tax-burden on two-earner couples

Keane and Moffitt (1998)

- increases in the Earned Income Tax
Immervoll, Kleven, Kreiner

- labor supply among two parent households sensitive to changes in the eligibility and benefit structure; AFDC-UP reduces hours of work (42-50 hours/month for husbands, 29-33 hours/month for wives);

- however, in the absence of the AFDC-UP $70 \%$ of families would retain eligibility for other welfare benefits;

- reducing tax rates on secondary earners by uniformly lowering the tax burden on two-earne couples financed by uniformly increasing the tax burden on zero- and one-earner couples increases second-earner participation but has no effect on primary-earner incentives to enter labor market

- financing the tax cut on two-earner couples by taxing only one-earner couples increases participation rates of primary earners and decreases participation of secondary-earners

- little effect of reduced taper rates (on AFDC and Food Stamp programmes) on employment and increased rates of program participation;

- subsidies to minimum wages more significantly than an increase in the gross hourly wage rate of $1 \$$ reduce participation in AFDC and Food Stamp programs and increases hours of work smaller effects of increases in the EITC;

- universal work subsidy increases participation mainly through effects on part-time work Credit (EITC);

- introduction of a universal work subsidy; (all reforms were hypothetical)

$\begin{array}{ll}\begin{array}{l}\text { Kornstad and Thoresen } \\ \text { (2007) }\end{array} & \begin{array}{l}\text { Norway: } \\ \bullet\end{array} \\ & \text { home care allowance - cash transfers } \\ & \text { for formal or parental child care; }\end{array}$

Laroque and Salanie (2008) France:

- child subsidy of 150 euros per month

- the subsidy if unconditional on work status would raise total fertility rate by $14,2 \%$ and decrease women labor participation of women by $1 \%$;

- if conditional on not working, the increase in fertility is lower $(10,3 \%)$ and the overall reduction in women participation higher $(2,4 \%)$ 


\section{Table A1 continued}

Lokshin (2004)

Russia:

- hypothetical introduction of free childcare;

- wage subsidies for working mothers or allowances to families;

Myck et al. (2006)

\section{Great Britain:}

Increasing generosity of the in-work

Working Families' Tax Credit (WFTC)

- without change of recipient (mothers)

- with change of recipient form main carer (mothers) to main earner;

Powell (2002)

\section{Canada:}

Hypothetical alternative reforms

including:

- formal childcare price subsidies;

- childcare subsidies to all forms of childcare;

- wage subsidies;

Prowse (2005)

\section{Great Britain:}

Hypothetical reforms in the form of $5 \%$

wage subsidies (duration of 1 year):

- for all workers

- for full time (FT) workers;

- for part time (PT) workers

Ribar (1995)

\section{United States:}

Alternative reforms to Child and

Dependent Care Tax Credit (CDCTC)

including:

- elimination of the CDCTC;

- CDCTC made fully refundable;

- CDCTC replaced with a flat $25 \%$ refundable childcare expenditure subsidy;
- fully subsidized formal childcare increases mothers' participation by $11,4 \%$.

- an alternative (the same cost to budget as previous reform) wage subsidy for mothers would increase participation of women by about $5,9 \%$, while a universal family allowance would result in slightly reduced female labor force participation;

- reforms modeled using a simplified collective framework - fewer women reduce their labor supply and more women respond by increasing hours of work if the higher WFTC is paid to the main earner;

- this results from lower female incomes and bargaining power if WFTC is paid to main earner;

- price subsidies targeted only to center care (10\% reduction) are found to have strong effects on childcare demand but modest employment effects

- childcare subsidies targeted to formal (center or sitter) care or not conditional of mode of care have the greatest effect on mothers' employment ( $12 \%$ and $13 \%$ respectively)

- wage subsidies increase employment of mothers by $9,5 \%$ together with the largest increase in formal childcare use;

- $\quad$ subsidies lead workers to switch from non-employment and part-time employment to full employment (in case of FT subsidies) and to part-time employment (in case of PT subsidies);

- dynamic effects suggest that after 6 years the effects of the policy disappear even in the case of subsidies to all workers (state dependence is not strong enough to preserve the effects in the long run);

- elimination of CDCTC would reduce married women's employment slightly;

- a refundable CDCTC would benefit low-income families without any effects on employment or childcare use;

- flat subsidy would have almost no effect on married women's labor force participation; any increase in childcare use would come from women working part-time; 


\section{Table A1 continued}

\begin{tabular}{|c|c|c|}
\hline Spiess and Wrohlich (2008) & $\begin{array}{l}\text { Germany: } \\
\text { - replacement of means-tested } \\
\text { parental leave benefit by wage- } \\
\text { dependent one year benefit }\end{array}$ & $\begin{array}{l}\text { - the reform does not induce significant changes to labour market outcomes in the first year } \\
\text { after birth but in the second year mothers increase their working hours (by almost } 12 \% \text { ) and } \\
\text { labour market participation (by } 9 \% \text { ) significantly }\end{array}$ \\
\hline Steiner and Wrohlich (2008) & $\begin{array}{l}\text { Germany: } \\
\text { - introducing three alternative forms } \\
\text { of family tax splitting }\end{array}$ & $\begin{array}{l}\text { - full family splitting induce strongest labor-supply effects (compared to french-style family } \\
\text { splitting and splitting with ceilings); average working hours for women in couples would } \\
\text { increase by } 3 \% \text {. and for single mothers by } 0,7 \% \text {; for men living in couples the labour-supply } \\
\text { effects would be smaller }\end{array}$ \\
\hline Todd and Wolpin (2006) & $\begin{array}{l}\text { Mexico: } \\
\text { Effect of the PROGRESA school } \\
\text { attendance subsidy program and } \\
\text { alternative proposals. }\end{array}$ & $\begin{array}{l}\text { - fertility outcomes are essentially invariant to the PROGRESA subsidies (4.24 children without } \\
\text { subsidy, } 4.28 \text { with the subsidy) } \\
\text { - doubling of the subsidy rises fertility from } 4.28 \text { to } 4.32 \text {; }\end{array}$ \\
\hline Van Soest, et al. (2002) & $\begin{array}{l}\text { Netherlands: } \\
\text { Alternative income tax reforms } \\
\text { including: } \\
\text { - tax allowances replaced by rate } \\
\text { reductions (1); } \\
\text { - tax allowances abolished for two } \\
\text { earner couples (2); } \\
\text { - tax allowances replaced by rate } \\
\text { reductions and allowances applied } \\
\text { individually (3); }\end{array}$ & $\begin{array}{l}\text { - labor supply effects for married men are always positive, though small } \\
\text { - reforms } 1 \text { and } 2 \text { would result in reductions in part-time work of less than } 20 \text { hours among } \\
\text { married women ( } 12,8 \% \text { and } 1,6 \% \text { respectively); } \\
\text { - the reform } 2 \text { would reduce and reform } 1 \text { would slightly increase the participation rate and } \\
\text { both reforms would still increase the number of hours worked } \\
\text { - reform } 3 \text { leads to larger increase in the number of women who choose a part-time job of more } \\
\text { than } 20 \text { hours and a larger increase in participation and average hours worked; }\end{array}$ \\
\hline Van Soest (1995) & $\begin{array}{l}\text { Netherlands: } \\
\text { - abolishing of possibility to transfer } \\
\text { tax allowance between partners; } \\
\text { - tax and benefits system is } \\
\text { individualized; }\end{array}$ & $\begin{array}{l}\text { - the first reform increases female labor supply by } 4.2 \% \text { and reduces male labor supply by } 0.7 \\
\% \text {. } \\
\text { the second reform reduces female labor supply by } 7.1 \% \text {, and the number of two earner } \\
\text { households decreases by } 14.5 \% \text {. }\end{array}$ \\
\hline Wrohlich (2011) & $\begin{array}{l}\text { Germany: } \\
\text { Reforms to childcare policies: } \\
\text { - increase in availability of subsidized } \\
\text { childcare slots conditional on } \\
\text { employment; } \\
\text { - abolishment of childcare fees for } \\
\text { children aged three to six; }\end{array}$ & $\begin{array}{l}\text { - the first reform leads to a large increase in participation rates for mothers with children up to } \\
\text { six years ( } 9 \%) \\
\text { - the second reform also leads to an increase in mothers' participation (4\%), however these } \\
\text { effects are smaller than those from the first reform }\end{array}$ \\
\hline
\end{tabular}

Source: authors' compilation. 